\title{
PHYTOCHEMICAL ANALYSIS AND ANTIOXIDANT ACTIVITY OF PURNAJIWA FRUIT EXTRACT (Euchresta horsfieldii (Lesch.) Benn.)
}

\author{
Romulia Trielva Apriliani, I Gede Putu Wirawan*, and Wayan Adiartayasa \\ Faculty of Agriculture, Udayana University \\ Jl. PB. Sudirman, Denpasar, Bali 80232, Indonesia \\ *Corresponding author: igpwirawan@unud.ac.id
}

\begin{abstract}
Antioxidant is a chemical compound that could give one or more electrons to inhibit the free radical reaction. One of the plants that potentially produce antioxidants is purnajiwa (Euchresta horsfieldii (Lesch.) Benn.). The research was conducted using the fruit of purnajiwa. The purpose of this study is to know antioxidant activity from purnajiwa fruit using the DPPH method and measured by UV-Vis spectrophotometry. The extract of purnajiwa fruit gained by the maceration method using $96 \%$ ethanol solvent. The results of phytochemistry screening found out that the extract contains flavonoid, alkaloid, saponin, tannin, and terpenoid. According to flavonoid testing using quercetin, the results obtained from purnajiwa extract contained flavonoid of $1,651 \mathrm{mg} \mathrm{QE} / \mathrm{g}$. The activity test of antioxidants quantitatively by DPPH using UV-Vis spectrophotometry found out that purnajiwa extract has IC50 value of 57,28 ppm so that purnajiwa extract has strong antioxidant activity that could be used as natural antioxidant resources.
\end{abstract}

Keywords: purnajiwa fruit, antioxidant activity, DPPH, UV-Vis spectrophotometre

\section{INTRODUCTION}

Polution, the chemical from food, alcohol, cigarettes, and UV radiation are sources of free radical that could damage the enviroment because of the characteristics were reactive and unstable. Free radical is a molecul that has one or more electron that unpairs in outer orbit so that to achieve molecular stability, free radicals will react to healthy body cells molecule by binding those molecular electrons (Sunarni et al., 2007). The results of free radical could be degenerative disease like cancer, tumor, stroke, and diabetes milletus. The risk of the disease caused by free radicals could be prevented by giving an antioxidant. The antioxidant is a compund that could decrease other molecular oxidation or to neutralize the free radical (Silalahi, 2006). Enough amounts of antioxidant could help the body to increase immunity through the disease that could be happened by free radical. Purnajiwa (Euchresta horsfieldii (Lesch.) Benn.) that one of the plants as natural antioxidant sources and known as traditional herbal that spread around countries such as India, Philipines, Thailand, and Indonesia. In 
Indonesia purnajiwa could be found in the special region in Bali famous as pranajiwa.

Morphologically, the shape of purnajiwa fruit is small, shining, oval around $1-2 \mathrm{~cm}$ length, the color of the raw fruit is green color and becomes purple when the fruit is ripe (Lemmens dan Bunyapraphatsara, 2003). Purnajiwa fruit has many benefits like for relief clogged up breathing, cough, asthma, and increasing the immunity. Purnajiwa has biological activities as it contained secondary metabolite compounds such as flavonoid, alkaloid, tannin, saponin, steroid, and terpenoid. Flavonoid has an ability as an antioxidant. Antioxidant research that has been done by Tirta $e t$ al., (2010) found out that the antioxidant capacity of pranajiwa leaves is about 126,94 ppm.

Antioxidant activity by purnajiwa fruit extract could be conducted by DPPH method. DPPH method has been used globally in antioxidant activity testing from natural compunds because it only needs a few sample, simple instrument, and fast processing. Antioxidant compunds from this sample given to the hydroxyl group through DPPH radical, so the DPPH radical that unstable before because of unpairs electron become stable (Purwaningsih, 2012). The antioxidants activity test from purnajiwa fruit extract in Indonesia is still rarely done, this is the reason why this antioxidant activity testing of purnajiwa fruit extract is conducted.

\section{MATERIALS AND METHODS}

Material used in this research is purnajiwa fruit species Euchresta horsfieldii that grow in Bajra Sandhi Monument, Puputan Renon, Denpasar City. The other material used as an extractor and chemical material for analysis is ethanol $96 \%$, DPPH, methanol absolut, eluen, chloride acid, magnesium, anhydrous acetate, sulfuric acid, Meyer reactor, $\mathrm{FeCl}_{3}$, aquadest.

The instrument that used are blender, oven, cutting board, knife, analitical scale, rotary evaporator, jar, micropipette, filter, pipette, refrigerator, volumetric flask, funnel, stirrer stick, erlenmayer, labeling paper, filtering paper, ruler, pencil, UV-Vis spectrophotometry, digital camera, cuvette, capillary pipe, vial, aluminium foil.

\section{Preparation sample}

Purnajiwa fruit was obtained in Bajra Sandhi Monument, Puputan Renon, Denpasar City then washed clean with flowing water, cut it to the small pieces with $\pm 0,5 \mathrm{~cm}$. The next step, dried up samples by oven with temperature $50^{\circ} \mathrm{C}$ around 48 hours. Mash the dried purnajiwa fruit using blender and measure the powder is weight using analitical scale. 


\section{Extraction of purnajiwa fruit}

About $500 \mathrm{~g}$ added by $96 \%$ ethanol solvent until submerged, then left it for 24 hours. After that filter it and separate the filtrate. Repeat this treatment about three times. At the last day of filtering, extract the filtrate using vacum rotary evaporator to obtained the extract.

\section{Screening phytochemical}

Flavonoid

About $1 \mathrm{ml}$ purnajiwa fruit solvent added by 10 drops magnesium hydrochloric acid, and shake for 1 minute. Presence of red color indicates the presence of flavonoids.

\section{Saponin}

About $1 \mathrm{ml}$ purnajiwa fruit solvent added by 10 drops aquadest, and shake for 1 minute. Presence of bubbles indicates the presence of saponin.

\section{Alkaloid}

About $1 \mathrm{ml}$ purnajiwa fruit solvent added by 3 drops Mayer reactor, and shake for 1 minute. Presence of white precipitate indicates the presence of alkaloids.

\section{Tanin}

About $1 \mathrm{ml}$ purnajiwa fruit solvent added by 3 drops solvent $\mathrm{H}_{2} \mathrm{SO}_{4}$ and 3 drops $\mathrm{FeCl}_{3}$ then shake for 1 minute. Presence of green color indicates the presence of tannin.

\section{Terpenoid}

About $1 \mathrm{ml}$ purnajiwa fruit solvent added by 5 drops anhydrous acetate dan 5 drops sulfuric acid. Presence of purple color indicates the presence of terpenoid

\section{Steroid}

About $1 \mathrm{ml}$ purnajiwa fruit solvent added by 5 drops anhydrous acetate dan 5 dropssulfuric acid. Presence of blue color indicates the presence of steroid.

\section{Flavonoid compound test}

\section{Preparation of purnajiwa fruit extract solvent}

$0,0176 \mathrm{~g}$ purnajiwa fruit extract added by $5 \mathrm{ml}$ methanol and then homogenize it with and centrifuge with $3000 \mathrm{rpm}$ about 15 minute. Take $1 \mathrm{ml}$ solvent of purnajiwa fruit extract and put it in the reaction bottle, add 1 $\mathrm{ml}$ aquadest and $0,1 \mathrm{ml} \mathrm{NaNO} 2$ then vortex it. After that add by $0,3 \mathrm{ml} \mathrm{AlCl}_{3}$ and vortex again. Next, add $1 \mathrm{ml} \mathrm{NaOH}$ with $1 \mathrm{ml}$ aquadest. Vortex all the mixing solvent and incubate it about 30 minutes, then scale the uptake absorbance using UV-VIS spectrophotometre in $415 \mathrm{~nm}$.

\section{Preparation of curve quercetin standard}

About $0,01 \mathrm{~g}$ quercetin powder dissolved in methanol up to $100 \mathrm{ml}$ volume to volumetric flask then make a concentration series $0,4,8,12,16,20 \mathrm{mg} / \mathrm{l}$. Pipette each solvent about $1 \mathrm{ml}$ then put in reaction bottle and add $1 \mathrm{ml}$ aquadest with $0,1 \mathrm{ml} \mathrm{NaNO} 2$ then homogenize the solvent using a vortex. Next on, adding $0,3 \mathrm{ml} \mathrm{AlCl} 3$ then vortex 
again. After that add $1 \mathrm{ml} \mathrm{NaOH}$ and $1 \mathrm{ml}$ aquadest. Vortex all the mixing solvent and incubate for about 30 minutes. After that, each solvent scale uptake absorbance using spectrophotometer UV-Vis in $415 \mathrm{~nm}$ wavelength.

The analysis of the standard quercetin solvent results to get the equation curve curve regression linear $y=a x+b$. The amount of equation linear regression used to measure the flavonoid content (mg QE/ g extract) is by the formula:

$$
\text { Flavonoid content }=\frac{\text { concentrate quercetin }}{\text { concentrate extract }} \times 100
$$

\section{Antioxidant activity of purnajiwa fruit extract}

About $0,0176 \mathrm{~g}$ purnajiwa fruit extract is filled with up to $5 \mathrm{ml}$ methanol to volumetric flask Make the concentration series of the solvent : $0,00,0,01,0,03,0,04$, $0,06 \mathrm{mg} / \mathrm{ml}$. Pipette each the concentration for $0,1 \mathrm{ml}$ solvent sample and add it to reaction bottle with $3,5 \mathrm{ml}$ DPPH online, vortex the mixing solvent and incubate in dark place with temperature of $37^{\circ} \mathrm{C}$ for 30 minutes. After that, each solvent scale uptake absorbance using UV-Vis spectrophotometery in $517 \mathrm{~nm}$ wavelenght. The percentage of antioxidant activity is measured by the formula :
A. Antioxidant $\frac{\text { abs.blanko-abs. sample }}{\text { abs.blanko }} \times 100 \%$

From the data percentage of antioxidant activity gained through the equation curve of linear regression $y=a x+b$ and converted to $\mathrm{IC}_{50}$ value. y amount is 50 and $\mathrm{x}$ amount as the concentration of the sample. A compound could be a powerful antioxidant if the amount of $\mathrm{IC}_{50}$ is less than $50 \mathrm{ppm}$, powerful if the amount of $\mathrm{IC}_{50}$ about $50-100 \mathrm{ppm}$, medium if the amount of $\mathrm{IC}_{50}$ is about 100-200 ppm, and weak if the amount of $\mathrm{IC}_{50}$ is more than $200 \mathrm{ppm}$ (Tristantini et al., 2016).

\section{RESULTS AND DISCUSSION}

\section{Screening phytochemical}

Phytochemistry screening must be done to identify the secunder metabolit of the purnajiwa extract. The rseult showed in the Table 1.

Phytochemical screening from purnajiwa fruit extract marked by the changing of color as a positive result. Reactor solvent from each compound could change the color of phytochemical screening because the binding is compatible between each secondary metabolite compound inside purnajiwa fruit. 
Table 1. Screening phytochemical of purnajiwa fruit extract

\begin{tabular}{cccc}
\hline Compound & Reactor & Result & Information \\
\hline $\begin{array}{c}\text { Flavonoid } \\
\text { Saponin } \\
\text { Alkaloid }\end{array}$ & $\begin{array}{c}\mathrm{HCl} \\
\text { Aquadest } \\
\text { Mayer }\end{array}$ & $(+)$ & $\begin{array}{c}\text { Red } \\
\text { Bubbles } \\
\text { White deposits on the } \\
\text { test tube wall. }\end{array}$ \\
Tanin & $\mathrm{FeCl}_{3}$ & $(+)$ & Green \\
Terpenoid & $\begin{array}{c}\text { Lieberman } \\
\text { Burchard } \\
\text { Lieberman } \\
\text { Burchard }\end{array}$ & $(+)$ & Purple \\
Steroid & $(-)$ & Blue \\
\hline
\end{tabular}

The results of purnajiwa fruit extract contain flavonoid, saponin, tanin, alkaloid, and terpenoid. The presence of red color from $\mathrm{HCl}$ rector indicates the presence of flavonoid, the presence of stable bubbles indicates the presence of saponin, the presence of white precipitate from Mayer reactor indicates the presence of alkaloid, the presence of green solvent from $\mathrm{FeCl} 3$ reactor indicates the presence of tannin, the presence of purpleblack color from Lieberman Burchard reactor indicates the presence of terpenoid. The extract doesn't contain steroids as there was no color changing into the blue. Steroid Is a non polar compound which can not be paired with ethanol which is a polar solvent (Arianti et al., 2007).

\section{Flavonoid test of purnajiwa fruit extract}

The purpose of total flavonoid content testing is to determine the amound of flavonoid contained is purnajiwa fruit extract. The research is conducted by quercetin. Quercetin is an active substance in the flavonoid compound group (Robinson, 1995). The determination of flavonoid content is conducted by measurement of wavelength concentration of purnajiwa fruit extract and quercetin solvent with UV-Vis spectrophotometry using $415 \mathrm{~nm}$ wavelength.

The results show that purnajiwa fruit extract has contained flavonoid about 1,651 $\mathrm{mg} \mathrm{QE} / \mathrm{g}$. The greater of flavonoid content, the more flavonoid compound that bound (Tim, 2006). The existence of flavonoid compound inside purnajiwa fruit extract caused because there is balancing between etanol solvent and flavonoid compound when maseration process so that flavonoid compound in purnajiwa fruit extract could be easily bound. 


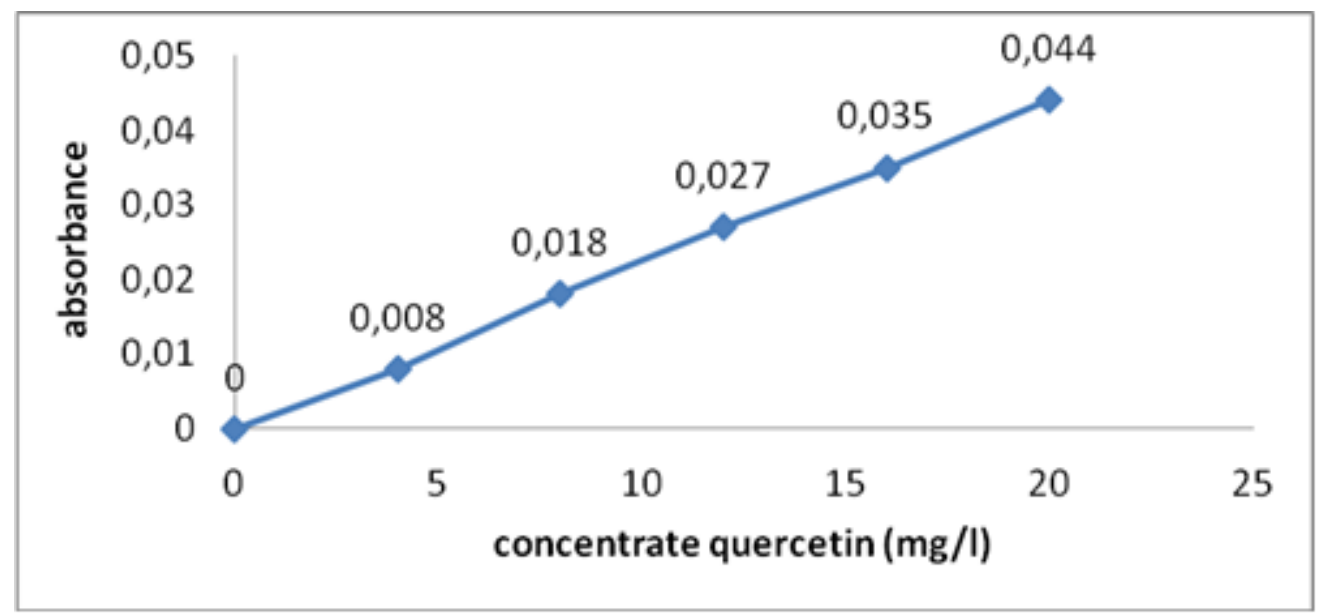

Fig. 1. quercetin linear regression curve of flavonoid

\section{Activity antioxidan test of purnajiwa fruit} extract

Purnajiwa fruit extract antioxidant activity test is conducted by the DPPH method. This method is used as it is simple to measure the antioxidant ability to catch free radicals in fast and it only needs a few materials to use. DPPH is a free radical molecule with a purple color that could change into the yellow color stable compound with antioxidant reaction, which antioxidant gives its one electron to DPPH so that damping happens to DPPH free radical. Free radical damping by antioxidant occur when unpaired electron being paired with donated hydrogen and form stable DPPH (Yuhernita dan Juniarti, 2011). Purnajiwa fruit extract created through the lowest to the highest concentration of DPPH solvent and being measured its absorbance absorption UV-Vis spectrophotometry using $517 \mathrm{~nm}$ wavelength. The results show as in Table 3.
Table 2. Quercetin measurement uses UV-Vis

\begin{tabular}{ccc}
\hline $\begin{array}{c}\text { Concentrate } \\
\text { quercetin (mg/l) }\end{array}$ & Absorbance \\
\hline 0 & 0,000 \\
4 & 0,008 \\
8 & 0,018 \\
12 & 0,027 \\
16 & 0,035 \\
20 & 0,044 \\
\hline spectrophotometre \\
Table 3. Result & of antioxidant activity \\
measurements & using & UV-Vis \\
spectrophotometre \\
\hline Concentrate & Absorbance & Antioxidant \\
extract & \multicolumn{2}{c}{ activity } \\
\hline Blanko & 0,446 & 0,000 \\
0,01 & 0,382 & 14,350 \\
0,03 & 0,320 & 28,251 \\
0,04 & 0,268 & 39,910 \\
0,06 & 0,241 & 45,964 \\
& &
\end{tabular}

Reducing of absorbance amount indicate that DPPH molecule successfully reduced because of reaction between 
antioxidant compound (Molyneux, 2004). their hydrogen atom from the aromatic ring The increasing of antioxidant activity to reduce free radicals that unstable to stable percentage of purnajiwa fruit extract free radicals (Amic et al., 2003). According influences the damping DPPH free radical. to Markham (1988), the flavonoid compound Hanani et al., (2015) stated that antioxidant is polar that soluble in ethanol solvent and activity percentage will increase as long as the concentration increases. The more molecule in antioxidant compound, the more antioxidant activity increased. (Talapessy et has the potential to have significant antioxidant activity. The more flavonoid compound, the higher the antioxidants al., 2013).

Data in Table 3 shows the curve of correlation equation by purnajiwa fruit extract with $\%$ antioxidant activity. As for curve linear regression equation from antioxidant activity test of purnajiwa fruit extract is shown in picture 2 .

Antioxidant activity testing by DPPH to purnajiwa fruit extract gained amount $\mathrm{IC}_{50}$ about 57,28 ppm. Based on Tristantini et al., (2016) the amount of IC $_{50}$ between 50 - 100 ppm has a powerful antioxidant activity. Purnajiwa fruit extract has a powerful antioxidant activity as the presence of secondary metabolite compounds inside, a flavonoid. The relation between flavonoid compound to antioxidant activity by DPPH method is high (Maisuthisakul dan Pasuk, 2007). This statement supported by Hardiana et al., (2012) that stated that the flavonoid compound role as an antioxidant activity because it has a hydroxyl group that could donate its hydrogen atom to free radical compound. Flavonoid compounds donate 


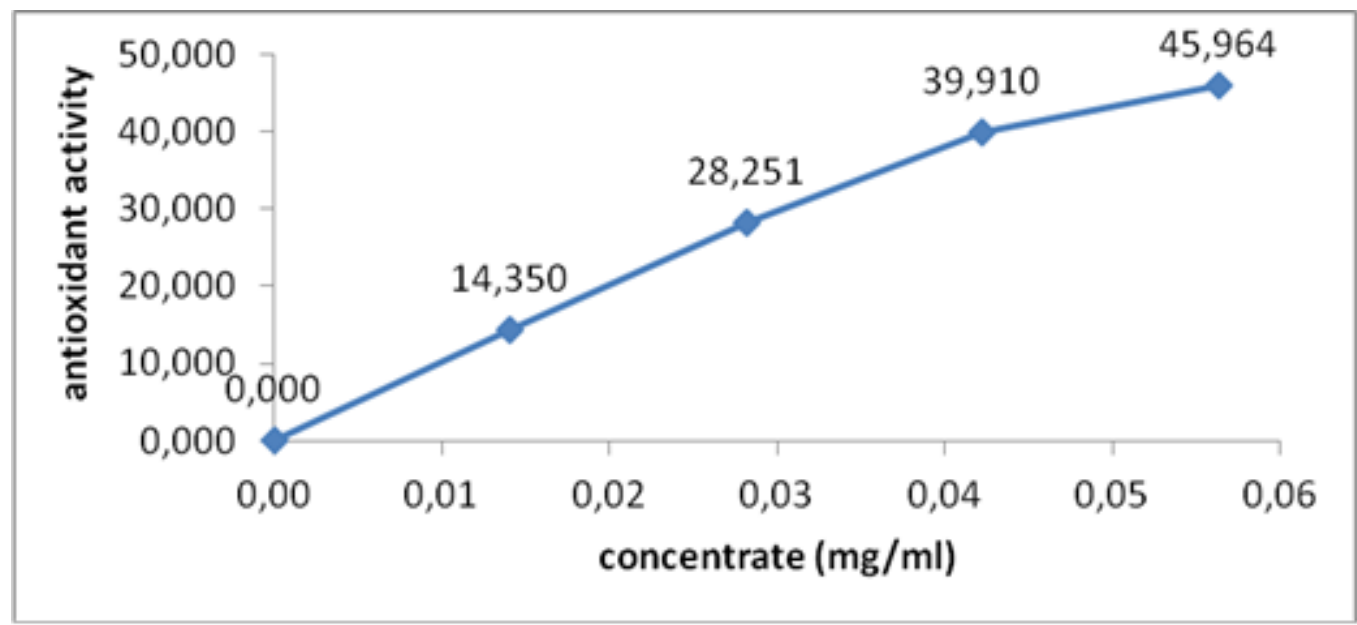

Fig. 2. linear regression curve of antioxidant activity

\section{CONCLUSION}

Purnajiwa fruit extract has secondary metabolite compounds which are alkaloid, saponin, flavonoid, tannin, and terpenoid. Purnajiwa fruit extract contains about 16,51\% flavonoids. The results of antioxidant activity by DPPH method from purnajiwa fruit extract has an amount IC50 about 57,28 ppm which is classified as a powerful antioxidant activity.

\section{ACKNOWLAGEMENTS}

This study was supported by Udayana University Research Grant No. : 8382/UN14.4.A/LT/2019.

\section{REFERENCES}

Amic, D., Beslo. D., Trinajstic, N., Davidovic. 2003. Structure-Radical Scavenging Activity Relationships of Flavonoids. Croatia Chem Acta, 76 (1): 55-61.

Arianti, Harsojo, Syafria, Y. dan Ermayanti, T. M. 2007. Isolasi dan Uji Antibakteri Batang Sambung Nyawa (Gynura procumbens L.). Jurnal Bahan Alam Indonesia 6(2): 43-45.
Artini, P.E., K.W. Astuti dan N.K Warditiani. 2013. Uji fitokimia ekstrak etil asetat rimpang bangle (Zingiber purpureum Roxb.). Jurnal Farmasi Udayana 1 (3) : 1-7.

Firdiyani,F., T.W Agustini dan W.F Ma'ruf. 2015. Ekstraksi senyawa bioaktif sebagai antioksidan alami spirulina platensis segar dengan pelarut yang berbeda. JPHPI 18 (1) : 28-37.

Hanani, E., Mun'im, A. \& Sekarini, R., 2005, Identifikasi Senyawa Antioksidan Dalam Spons Callyspongia sp Dari Kepulauan Seribu, Majalah Ilmu Kefarmasian, Vol. II, No.3, 127 - 133.

Harbone, J.B., 1987. Metode Fitokimia Penuntun Cara Modern Menganalisis Tumbuhan. Terjemahan : Kosasih p, Soediro iwang, Bandung: ITB.

Hardiana, R., Rudiansyah. dan T.A Zaharah. 2012. Aktivitas Antioksidan Senyawa Golongan Fenol dari Beberapa Jenis Tumbuhan Famili Malvaceae. JKK 1: 8-13.

Maisuthisakul, P., dan Pasuk, S., 2007, Antioxidant Properties and Phenolic Phytochemicals From Various Cultivars of Thai Mango Seed Kernels, laporan penelitian, University of Thai Chamber of Comerce, Bangkok.

Molyneux, P., 2004. The Use of the Stabel Free Radical Diphenylpicryl Hydrazyl (DPPH) for Estimating Antioxidant Activity. Songklanakarin Journal 
Science and Technology. Vol 26: 211219.

Robinson, T., 1995, Kandungan Organik Tumbuhan Tinggi, Edisi VI, Hal 191216, Diterjemahkan oleh Kosasih Padmawinata, ITB, Bandung.

Rohman, A., Riyanto, S., Utari, D. 2006. Aktivitas Antioksidan, Kandungan Fenolik Total dan Kandungan Flavonoid Total Ekstrak Etil Asetat Buah Mengkudu Serta Fraksifraksinya. Jurnal MFI. 17(3), 136-142.

Sari, K.A.I., Gunawan, I.W.G. \& Putra, K.G.D., 2015. Kapasitas Antioksidan Senyawa Golongan Triterpenoid Pada Daun Pranajiwa (Euchresta horsfieldii lesch benn). Jurnal Kimia 9 (1): 61-66. Silalahi, J. 2006. Makanan Fungsional. Kanisius Press, Yogyakarta.

Sunarni, T., Pramono, S., \& Asmah, R., 2007. Flavonoid Antioksidan Penangkap Radikal dari Daun Kepel (Stelechocarpus burahol). Majalah Farmasi Indonesia. 18 (3): 111-116.

Talapessy, S., Suryanto, E. dan Yudistira, A. 2013. Uji aktivitas antioksidan dari ampas hasil pengolahan sagu (Metroxylon sagu). Jurnal Ilmiah Farmasi, 2(3): 40-44.

Tirta, I.G., Ardaka, I.M. \& Darma, I.D.P., 2011. Study Autekologi Pranajiwa (Euchresta horsfieldii (Lesch.) Benn) di Bukit Pengelengan, Desa Pancasari, Kecamatan Sukasada, Kabupaten Buleleng, Bali. Buletin Kebun Raya. 14 (1): 10-13.

Trisantini, D., A.Ismawati., B.T.P Jonathan dan J.G. Jonathan. 2016. Pengujian aktvitas antioksidan menggunakan metode DPPH pada daun tanjung (Mimusops elengi L.). Prosiding Seminar Nasional Teknik Kimia "Kejuangan" G1-1 - 7 .

Yuhernita dan Juniarti. 2011. Analisa Senyawa Metabolit Sekunder dari Ekstrak Metanol Daun Surian yang Berpotensi sebagai Antioksidan. Makara, Sains. 15(1): 48-52.
Yulianti. 2011. Skrining dan Analisis KLTBioautograf i Senyawa Antimikroba Beberapa Ekstrak Spons Asal Perairan Laut Pulau Barrang Lompo, Sulawesi Selatan. Majalah Obat Tradisional, 16 (02), 88-94. 
